\title{
Experimental Study on Toe Scouring at Sloping Walls with Gravel Foreshores
}

\author{
M. Salauddin *D and J. M. Pearson \\ School of Engineering, University of Warwick, Coventry CV47AL, UK \\ * Correspondence: m.salauddin@warwick.ac.uk
}

Received: 18 May 2019; Accepted: 25 June 2019; Published: 27 June 2019

\begin{abstract}
Sea defences, such as urban seawalls can fail due to the development of a scour hole at the toe of the structure. The scour depth or the information on ground levels at the structure toe is required for the sustainable management of coastal defences, due to its influence on the structural performance. This research reports and summarises the main findings of a new laboratory study on toe scouring at a smooth sloping wall with permeable gravel foreshore. A set of small-scale laboratory experiments of wave-induced scouring at sloping seawalls were conducted. Two gravel sediments of prototype $d_{50}$ values of $13 \mathrm{~mm}$ and $24 \mathrm{~mm}$ were used to simulate the permeable 1:20 (V:H) gravel beach configurations in the front of a smooth 1 in 2 sloping wall. Each experiment comprised of a sequence of around 1000 random waves of a JONSWAP energy spectrum with a peak enhancement factor of 3.3. The relationship of the scour depth with toe water depth, Iribarren number, and wall slope were investigated from the test results of this work and through a comparison with available datasets in the literature. The results of this study showed that the relative toe water depth and Iribarren number influence the relative toe scour depth at a sloping structure on a shingle beach. Within the experimental limitations, the maximum toe scour depths were observed for the experiments under spilling and plunging wave attack.
\end{abstract}

Keywords: physical model experiments; scouring; shingle foreshore; sloping wall

\section{Introduction}

Toe scouring at a coastal structure is usually defined as the development of a scour hole at the toe of the structure. This may eventually lead to the deterioration and damage of the structure through the redistribution of the sediment near the toe of the structure under the wave action over time $[1,2]$. Sea defences, such as urban seawalls in the United Kingdom (UK), can fail because of this toe scouring phenomenon, see [3-5]. In addition, climate change is believed as one of the most crucial challenges encountering mankind [6] in today's world. The combined influence of climate change and global sea level rise, which is expected as $4 \mathrm{~mm} /$ year for the 21st century [7] by the IPCC (Intergovernmental Panel on Climate Change) set a long-standing threat of coastal hazards on the sea defences in nearshore regions. The scour depth or the information on ground levels at the structure toe is required for the sustainable management of coastal defences in response to climate change, due to its influence on the structural performance [8].

Many researchers have performed laboratory and field research over the years, to improve the understanding of this phenomenon and, to provide design guidance on toe scouring at coastal structures with sandy foreshores, for example [4,9-12]. In 2008, [1] provided an overview of experimental and field studies on toe scouring at vertical breakwaters on sandy foreshore configurations. Some numerical researches have been performed in recent years to understand the scouring patterns at coastal structures in addition to physical studies, see [13-16]. 
Investigations on vertical walls showed that the toe scour depth and relative toe water depth is strongly correlated for sandy beach configurations, see [1,17]. For instance, for the prediction of scour depth at vertical seawalls with sandy beach, [17] and [8] established an empirical relationship (Equation (1)) between the dimensionless scour depth $\left(S_{t} / H_{s}\right)$ and relative toe water depth $\left(h_{t} / L_{0 m}\right)$. For a known beach slope, these authors suggested another empirical equation to predict the toe scour depth at vertical walls with sandy beaches, see Equation (2).

$$
\begin{gathered}
\frac{S_{\text {tmax }}}{H_{S}}=4.5 \mathrm{e}^{-8 \pi\left(h_{t} / L_{m}+0.01\right)}\left(1-\mathrm{e}^{-6 \pi\left(h_{t} / L_{0 m}+0.01\right)}\right) \quad\left[-0.013 \leq h_{t} / L_{0 m} \leq 0.18\right] \\
\frac{S_{t}}{H_{S}}=6.8(0.207 \ln (\alpha)+1.51) \mathrm{e}^{-5.85 k_{m} h_{t}}\left(1-\mathrm{e}^{-3 k_{m} h_{t}}\right)-0.137 \quad\left[-0.04 \leq h_{t} / L_{0 m} \leq 0.12\right]
\end{gathered}
$$

in which $S_{t \max }$ is the maximum toe scour depth, $S_{t}$ is the toe scour depth, $H_{s}$ significant wave height defined as highest one-third of wave heights $=H_{1 / 3}, \alpha$ is the beach slope, $h_{t}$ is the toe water depth, and $L_{0 m}$ is the deep-water wave length based on mean wave period $T_{m}$.

Powell et al. [18] conducted a laboratory study with prototype sediment diameters of $5<\mathrm{d}_{50}<30 \mathrm{~mm}$ in a model scale of 1:17 and derived a dimensionless scour plot for the approximation of scour depth at the vertical walls on shingle beds. Based on a laboratory study on scour depths at vertical structures with a sandy slope and two gravel slopes, [19] proposed an empirical relationship between the maximum wave height at the toe of the slope, submergence of the berm, and local wave length to estimate the scour depth at this type of sea defence. Nevertheless, these empirical predictions have not been validated with other datasets.

Recently, [20] performed an extensive laboratory investigation on the toe scour depths at vertical breakwaters with two permeable shingle beaches. The authors showed that there is a strong relationship between scour depths with relative toe water depth and Iribarren number for shingle foreshores, as observed by [12] on sandy beaches. As expected, the maximum scour depths were reported for spilling and plunging waves $\left(0.005 \leq h_{t} / L_{0 m} \leq 0.04\right)$.

In comparison to the vertical walls, there have been surprisingly few studies devoted to the toe scouring at sloping walls with both sandy and permeable shingle beach configurations. In 2006, [12] investigated scouring at a 1 in 2 sloping wall, as well as at a plain vertical wall on a sandy beach. The authors postulated that toe scouring are independent of the slope of the structure and claimed that the scour depths at sloping walls do not differ from those reported at vertical walls. To date, little knowledge is available regarding the scouring at sloping walls with permeable shingle beach configurations.

This study investigated the toe scouring at sloping walls on shingle foreshores. In addition to scour depths, the profile of foreshore slope after a wave attack was also investigated. This research reports and summarizes the main findings of a new laboratory study on toe scouring at a sloping seawall with the permeable shingle foreshore slope. A set of small scale laboratory experiments of wave-induced scouring at sloping seawalls has been conducted in a wave flume at the University of Warwick. Two gravel sediments of prototype $d_{50}$ values of $13 \mathrm{~mm}$ and $24 \mathrm{~mm}$ were used to simulate the permeable 1:20 (V:H) gravel beach configurations at smooth 1 in 2 sloping walls. The findings of this laboratory study provide the data and comprehensive knowledge that are required to understand the toe scouring phenomenon at a sloping structure with a gravel foreshore.

\section{Laboratory Set-Up}

The small-scale physical experiments were performed in the wave channel within the school of engineering at the University of Warwick. The two-dimensional (2D) wave flume is approximately $22 \mathrm{~m}$ long, $0.60 \mathrm{~m}$ wide, and has an operating depth of $0.40 \mathrm{~m}-0.70 \mathrm{~m}$. The wave channel is equipped with an active absorbing-piston type wave paddle, enables simulating both uniform and random sea state within the flume. The physical experiments were carried out on a plain (prior to start the test) 1 in 20 permeable shingle beach in front of a smooth impermeable 1:2 (V:H) sloping seawall. In Figure 1, 
a layout of laboratory set-up that was used in this work to carry out physical experiments on scouring at 1 in 2 smooth sloping walls is presented.

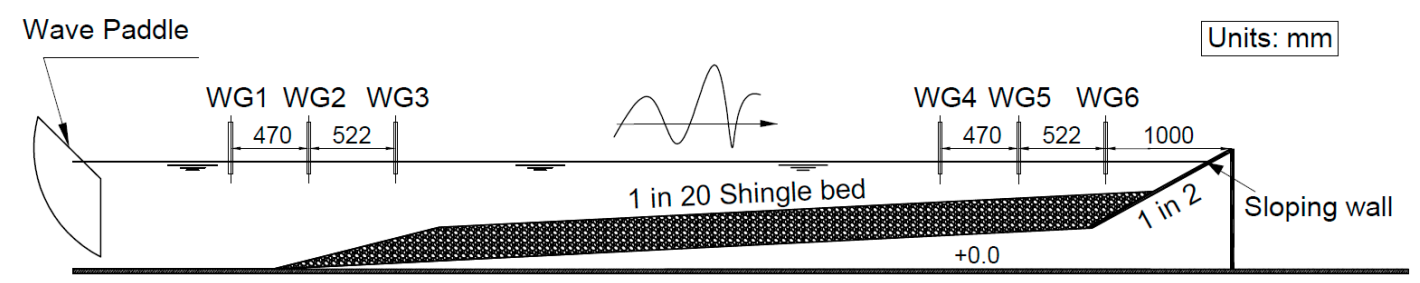

Figure 1. Laboratory set-up used for physical experiments on scouring at a 1 in 2 sloping wall.

In generally, the correct representation of beach permeability, the threshold of sediment mobility, and the relative magnitudes of onshore/offshore movement are the three main requirements to reproduce a gravel beach within the laboratory, as suggested by Powel [21]. The model sediments have only two parameters (size and specific gravity); therefore, the proper representation of all three criteria is hardly achievable within the laboratory. Powel [21] reported that the crushed anthracite with a specific gravity of 1.39 is able to satisfy most of the requirements by modelling the appropriate threshold of motion and onshore/offshore movement. As following the approach that was recommended by Powel [21], the filtered anthracite coal of a specific gravity of $1.40\left(\mathrm{~T} / \mathrm{m}^{3}\right)$ was used to represent the gravel beach materials. Two different sediment sizes of gravel were used in this work, scaled adapting the methodology, as suggested by [21]. The tested model bed materials $d_{50}$ of $2.10 \mathrm{~mm}$ and $4.20 \mathrm{~mm}$ represent the prototype grain size $\mathrm{d}_{50}$ of $13 \mathrm{~mm}$ and $24 \mathrm{~mm}$, respectively, at a 1 in 50 scale with a prototype specific gravity of $2.65\left(\mathrm{~T} / \mathrm{m}^{3}\right)$, see details in [20]. It is important to note that any reference to the size of sediment within this paper has only been referred as prototype values, unless otherwise stated.

A 1:50 length scale was applied in this study to generate random wave conditions within the wave flume. Two constant nominal wave steepnesses $\left(\mathrm{s}_{\mathrm{op}}=0.02\right.$ and 0.05$)$ were tested to cover both wind sea state as well as swell sea conditions. A matrix of 120 test conditions (significant wave heights, wave steepnesses, crest freeboards, water depths, and gravel sizes) were covered to investigate scouring at the toe of the sloping structure, see Table 1. The test matrix that was followed within this study was developed by following the available guidelines for typical small-scale investigations, as reported in $[22,23]$. For example, the inshore significant wave heights that were tested in this study varied from $50 \mathrm{~mm}$ to $150 \mathrm{~mm}$, which is comparable to every good small-scale investigation. Furthermore, each experiment comprised of a sequence of around 1000 random waves of a JONSWAP (Joint North Sea Wave Project) energy spectrum, with a peak enhancement factor $\gamma=3.3$ to represent a typical storm of $3 \mathrm{~h}$.

The incident wave characteristics (wave heights and periods) were measured by determining the free water surface elevations at the six different locations along the wave flume during the experiments. The well-established three-point technique developed by Mansurd and Funke [24] was adapted to separate the incident waves from reflected waves. One set of three wave gauges were placed in relatively deep water (close to wave generator) to determine the deep-water wave characteristics. The next set of three gauges were fixed near the toe of the sloping wall to determine the incident wave conditions at the structure. The wave gauge (WG6) near the toe of the sloping wall was set by adapting the technique of Klopman and Van der Meer [25], which helps to reduce the effect of a reflective wall on the measurements. Further, the measurements of wave conditions were also repeated without the structure in place, in order to decrease any probable uncertainty in the measurement of the incident wave characteristics induced by the reflection. 
Table 1. Overview of test conditions.

\begin{tabular}{|c|c|c|c|c|c|}
\hline $\begin{array}{c}\text { Structural and } \\
\text { Bed Configuration }\end{array}$ & $\begin{array}{c}\text { Toe Water } \\
\text { Depth, } h_{\mathrm{t}} \\
{[\mathrm{mm}]}\end{array}$ & $\begin{array}{c}\text { Crest } \\
\text { Freeboard, } R_{\mathrm{c}} \\
{[\mathrm{mm}]}\end{array}$ & $\begin{array}{c}\text { Wave Height, } \\
H_{\mathrm{m} 0}[\mathrm{~mm}]\end{array}$ & $\begin{array}{c}\text { Wave } \\
\text { Steepness, sop } \\
{[-]}\end{array}$ & $\begin{array}{c}\text { Wave Period, } T_{p} \\
{[\mathrm{~s}]}\end{array}$ \\
\hline \multirow{12}{*}{$\begin{array}{l}\text { Sloping wall on a } \\
\text { shingle bed } \\
\mathrm{d}_{50}=13 \mathrm{~mm}\end{array}$} & \multirow{2}{*}{60} & \multirow{2}{*}{190} & \multirow{2}{*}{$50-160$} & 0.02 & $1.27-2.26$ \\
\hline & & & & 0.05 & $0.80-1.43$ \\
\hline & \multirow{2}{*}{75} & \multirow{2}{*}{245} & \multirow{2}{*}{ 50-160 } & 0.02 & $1.27-2.26$ \\
\hline & & & & 0.05 & $0.80-1.43$ \\
\hline & \multirow{2}{*}{100} & \multirow{2}{*}{150} & \multirow{2}{*}{$50-160$} & 0.02 & $1.27-2.26$ \\
\hline & & & & 0.05 & $0.80-1.43$ \\
\hline & \multirow{2}{*}{150} & \multirow{2}{*}{100} & \multirow{2}{*}{$50-160$} & 0.02 & $1.27-2.26$ \\
\hline & & & & 0.05 & $0.80-1.43$ \\
\hline & \multirow{2}{*}{180} & \multirow{2}{*}{140} & \multirow{2}{*}{$50-160$} & 0.02 & $1.27-2.26$ \\
\hline & & & & 0.05 & $0.80-1.43$ \\
\hline & \multirow{2}{*}{200} & \multirow{2}{*}{50} & \multirow{2}{*}{$50-160$} & 0.02 & $1.27-2.26$ \\
\hline & & & & 0.05 & $0.80-1.43$ \\
\hline \multirow{12}{*}{$\begin{array}{l}\text { Sloping wall on a } \\
\text { shingle bed } \\
\mathrm{d}_{50}=24 \mathrm{~mm}\end{array}$} & \multirow{2}{*}{60} & \multirow{2}{*}{190} & \multirow{2}{*}{$50-160$} & 0.02 & $1.27-2.26$ \\
\hline & & & & 0.05 & $0.80-1.43$ \\
\hline & \multirow{2}{*}{75} & \multirow{2}{*}{245} & \multirow{2}{*}{ 50-160 } & 0.02 & $1.27-2.26$ \\
\hline & & & & 0.05 & $0.80-1.43$ \\
\hline & \multirow{2}{*}{100} & \multirow{2}{*}{150} & \multirow{2}{*}{$50-160$} & 0.02 & $1.27-2.26$ \\
\hline & & & & 0.05 & $0.80-1.43$ \\
\hline & \multirow{2}{*}{150} & \multirow{2}{*}{100} & \multirow{2}{*}{$50-160$} & 0.02 & $1.27-2.26$ \\
\hline & & & & 0.05 & $0.80-1.43$ \\
\hline & \multirow{2}{*}{180} & \multirow{2}{*}{140} & $50-160$ & 0.02 & $1.27-2.26$ \\
\hline & & & & 0.05 & $0.80-1.43$ \\
\hline & 200 & 50 & $50-160$ & 0.02 & $1.27-2.26$ \\
\hline & 200 & & & 0.05 & $0.80-1.43$ \\
\hline
\end{tabular}

The scour depths were calculated with the use of a depth point gauge before and at the end of the experiment. The foreshore bed was reshaped to the initial uniform bed profile of 1 in 20 permeable gravel slope in the front of the structure, prior to the start run of each test. The scour depth at the toe of sloping wall $\left(S_{t}\right)$ and maximum scour depth $\left(S_{\max }\right)$ were measured for each experiment. In addition, scour depths were also measured at several locations along the foreshore slope to determine the bed profile of gravel beach after a random wave attack. This was executed with the use of the depth point gauges at fixed locations, and consequent analysis was performed.

\section{Results and Discussion}

\subsection{Inshore Wave Conditions}

For this study, the distributions of measured incident wave heights at deep water are plotted for each experiment and are compared with the expected Rayleigh distribution. Figure 2 represents the distribution of wave heights for deep water conditions (close to wave paddle) for two test configurations, and also compares the results with the estimated Rayleigh distribution. It is clearly seen from the graphs that the resulting data points show a good agreement with the Rayleigh distribution for both low and high wave steepness However, the measured wave heights were found to deviate from the expected Rayleigh distribution for very high waves, which may be a result of the limitations of paddle generation, such as the wave paddle stroke or wave breaking on the paddle. For the tested conditions, the reflection co-efficient varied from 0.25 to 0.45 at a relatively deep water, near the structure the 
observed values were in the range from 0.37 up to 0.79 near the structure. This is the reason why the experiments were also carried out without the structure in place to remove the structure induced reflection in the measurements.

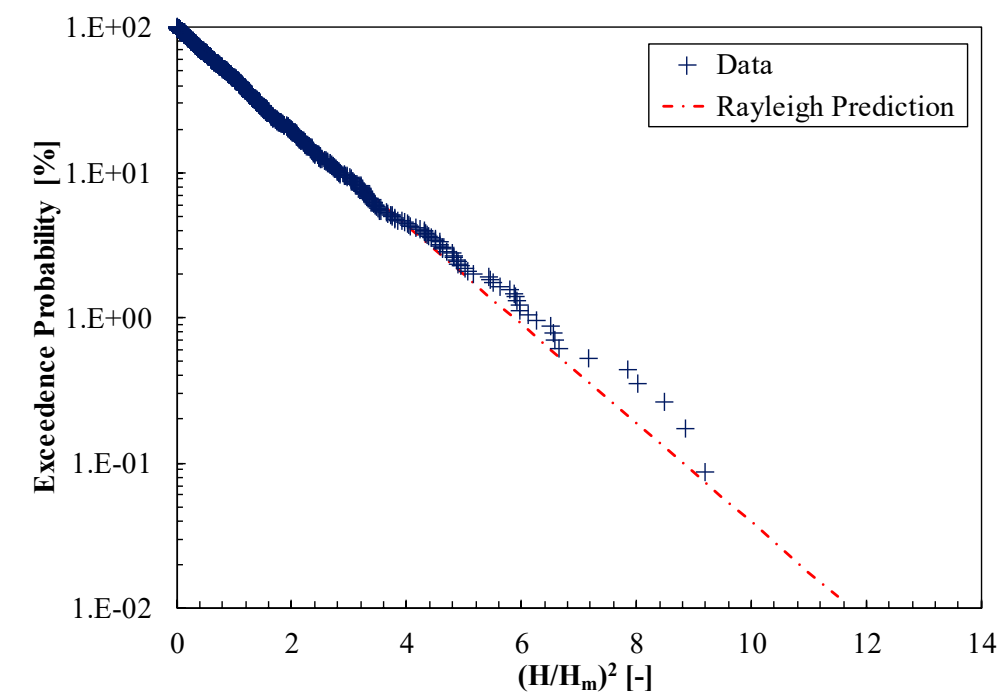

(a)

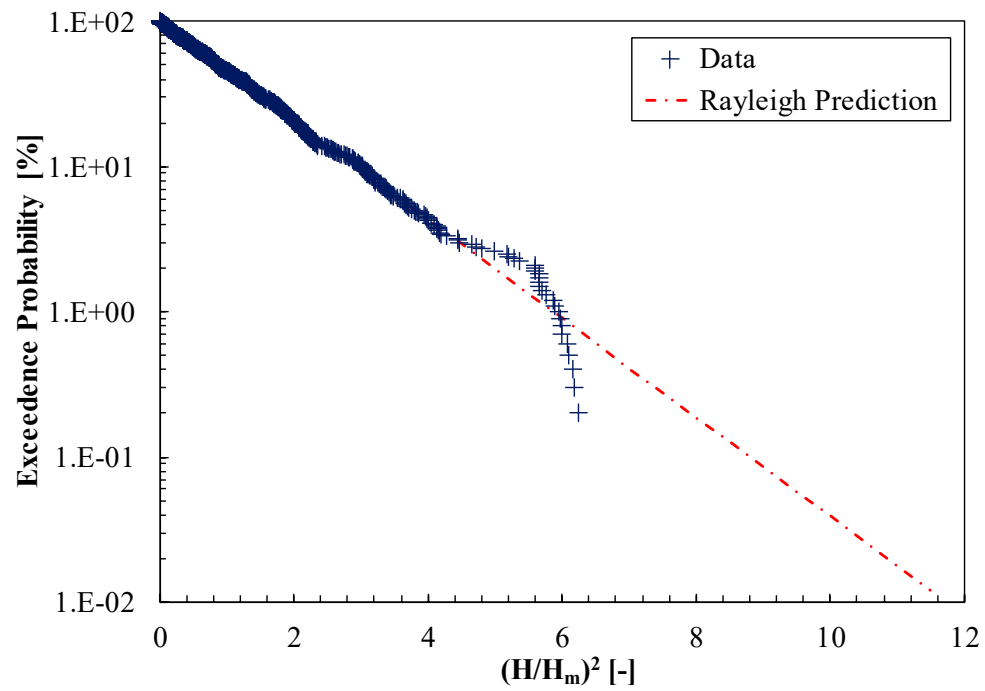

(b)

Figure 2. Comparison of the distribution of measured wave heights with the Rayleigh predictions- (a) $\mathrm{s}_{\mathrm{m}-1,0}=0.02, H_{m 0}=0.06 \mathrm{~m}(\mathbf{b}) \mathrm{s}_{\mathrm{m}-1,0}=0.06, H_{m 0}=0.078 \mathrm{~m}$.

\subsection{Relationship between Development of Scour Depth and Storm Duration}

The development of a scour depth has strong correlation with the storm duration or the number of waves [5]. In 2000, Sumer and Fredsøe [26] reported that the peak scour depth occurs between 1000-2000 irregular waves at a 1 in 1.2 seawall on a sandy bed. Recent investigations by [20] on the vertical breakwaters with shingle foreshores showed that the greatest scour depth occurs at around 1000 random waves.

In Figure 3, the time development of maximum scour depth is presented by plotting the measured scour depths against the number of waves. The experiments were performed with approximately 3000 random waves to observe the development of scour depths, where the measurements were conducted at around 1000, 2000, and 3000 waves, respectively. From the graph, it is noticeable that the maximum value of scour depth occurs at approximately 1000 waves, and it reveals similar features as reported by [20] for vertical walls. 


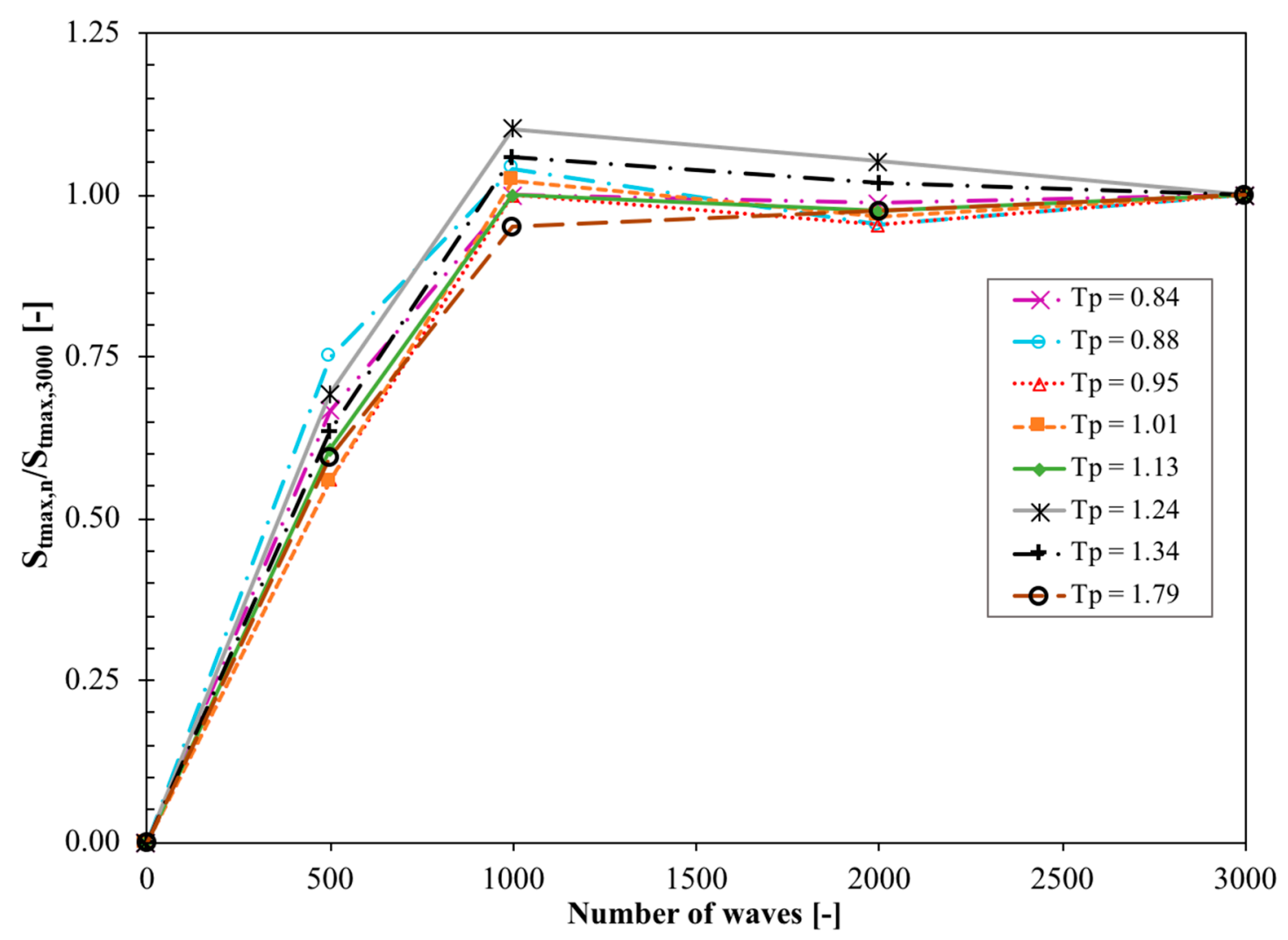

Figure 3. Relationship between development of scour depth and storm duration.

\subsection{Variation of Bed Level for a Sloping Wall with a Shingle Foreshore}

The variation of bed level (final elevation-initial elevation of foreshore) due to the random wave attack was inspected for the tested conditions within this study. In Figure 4, two examples of the measured bed level changes for swell ( $\mathrm{s}_{\mathrm{op}}$ of 0.02$)$ and storm $\left(\mathrm{s}_{\mathrm{op}}\right.$ of 0.05$)$ wave conditions are presented for six different toe water depths $\left(h_{t}=0.06 \mathrm{~m} ; 0.075 \mathrm{~m} ; 0.10 \mathrm{~m} ; 0.15 \mathrm{~m} ; 0.16 \mathrm{~m} ; 0.18 \mathrm{~m}\right)$. The data points correspond to positive values of bed changes denote accretion, whereas negative values indicate the scouring at the structure. Figure 4 demonstrates that the maximum accretion or scouring at the structure occurs for the lowest toe water depth for a known wave condition. To cite an example, if we look at the measured data points corresponding to swell waves ( $\mathrm{s}_{\mathrm{op}}$ of 0.02 ) in Figure $4 \mathrm{a}$, it is noticeable that the greatest accretion of $0.098 \mathrm{~m}$ occurs at the lowest water depth of $0.06 \mathrm{~m}$.

From the graphs, it is also observed that the storm waves generate scouring, while the swell waves provide accretion at the structure for a certain water depth. This may happen due to the two different wave characteristics, which actually dominate the movement or transport of beach materials. Generally, steep storm waves generate scouring at gravel beaches through offshore sediment transport, whereas swell waves (long waves) provide accretion of onshore sediment transport of bed materials [27]. Similar characteristics of accretion and erosion with respect to long and short waves were also observed by [20] for plain vertical walls on shingle foreshores. 


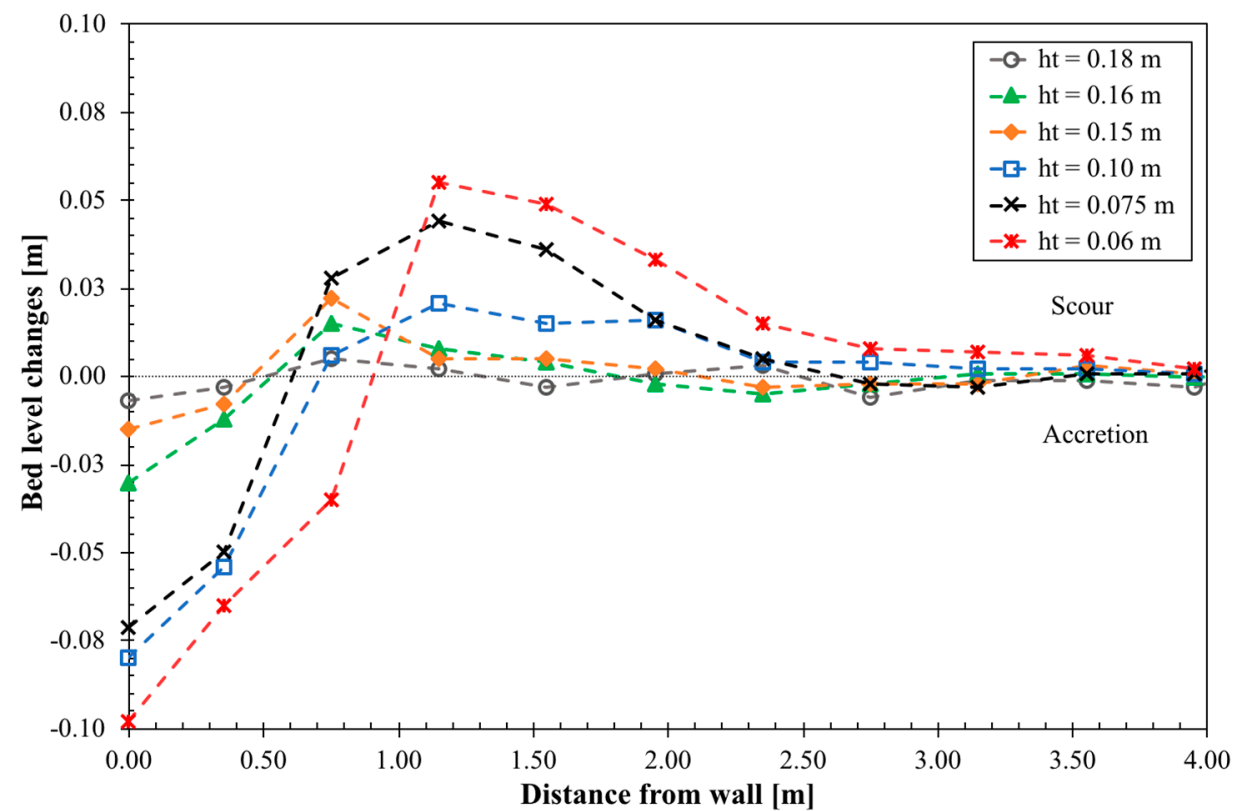

(a)

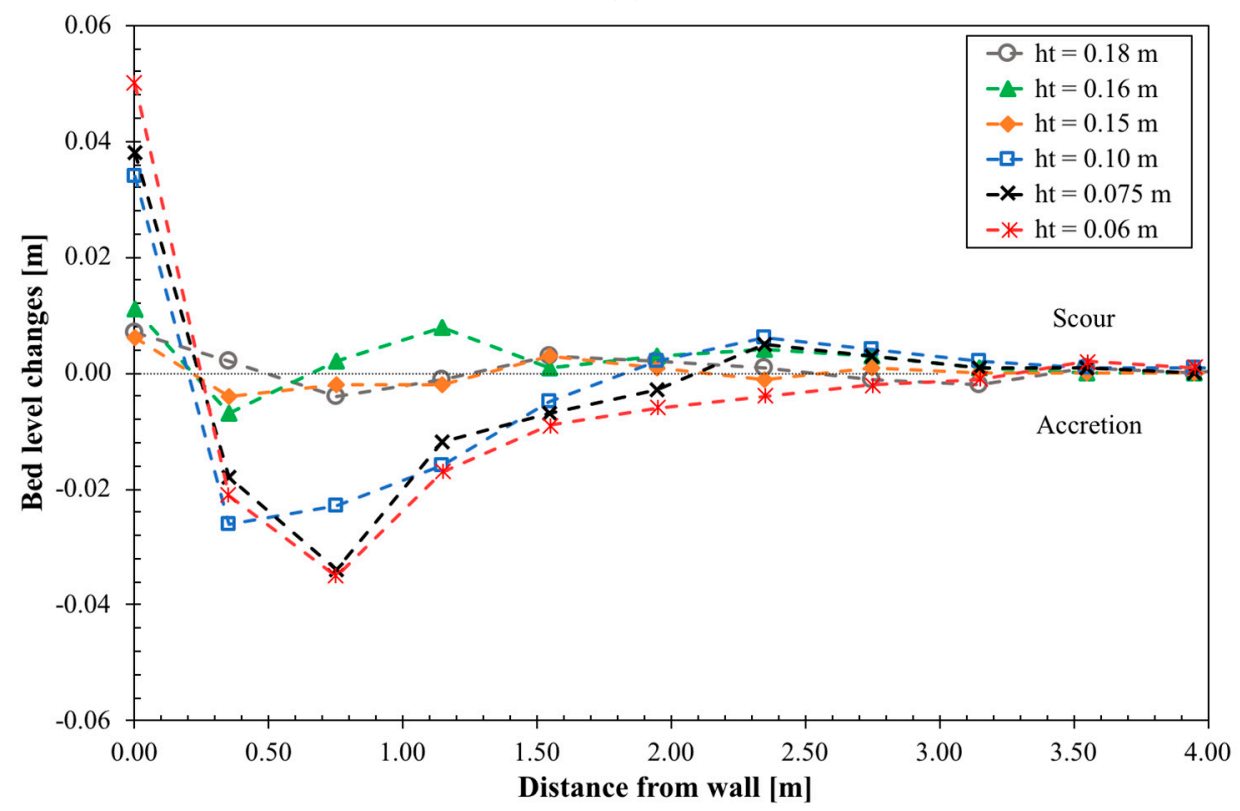

(b)

Figure 4. Bed level changes after 1000 waves-(a) $\mathrm{s}_{\mathrm{op}}=0.02, H_{m 0}=0.07 \mathrm{~m}(\mathbf{b}) \mathrm{s}_{\mathrm{op}}=0.05, H_{m 0}=0.10 \mathrm{~m}$.

\subsection{Variation of Toe Scour Depth with Relative Water Depth}

Figure 5 shows the variation of the measured relative scour depth with relative water depth at the toe of the structure. The dashed line represents the trend of scour depths at seawalls with sandy foreshores, as reported by [8]. The negative values of relative toe water depth indicate the presence of an extended beach above the still water level prior to the start of the experiment, whereas negative non-dimensional toe scour depths denote the accretion at the structure.

The resulting data points show that the maximum scouring at the toe of the structure occurs under the spilling and plunging wave conditions $\left(0.005 \leq h_{t} / L_{0 m} \leq 0.04\right)$. Similar trends of scour depths under spilling and plunging impacts are also noticeable from the scouring predictions of [8], see Figure 5 . For the tested conditions, the maximum erosion at the toe of the structure is observed $\mathrm{S}_{\mathrm{t}} / \mathrm{H}_{1 / 3}=0.93$ at 
a relative toe water depth $\left(h_{t} / \mathrm{L}_{0 m}\right)$ of around 0.01 and the maximum accretion is noted $\mathrm{S}_{\mathrm{t}} / \mathrm{H}_{1 / 3}=1.51$ at a relative toe water depth $\left(h_{t} / L_{0 m}\right)$ of about 0.03 .

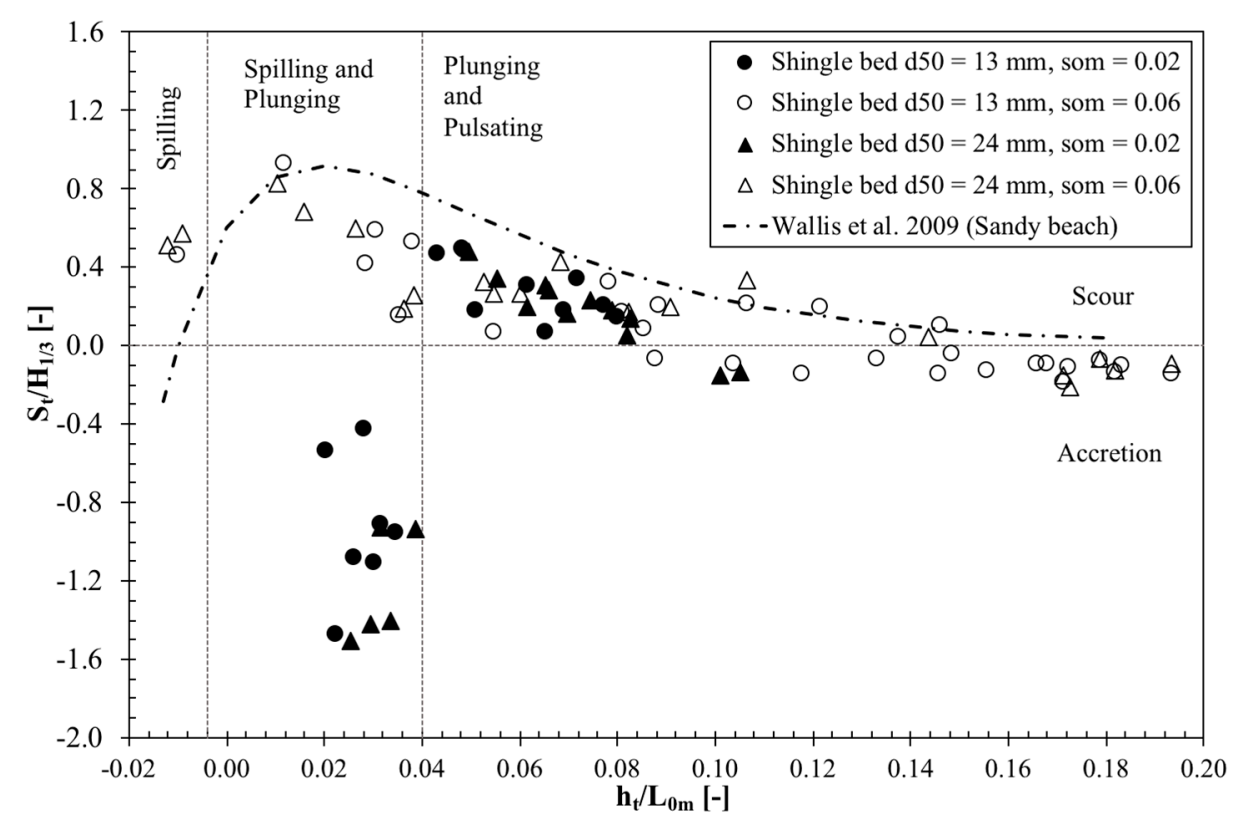

Figure 5. Variation of non-dimensional toe scour depth at a sloping wall with relative toe water depth.

In Figure 5, another clear aspect is that, under plunging and pulsating (surging) breakers $\left(h_{t} / L_{0 m}>\right.$ $0.04)$, the scour depths continued to decrease with the increase of the relative toe water depth. For the data points corresponding to relatively higher toe water depths $\left(h_{t} / L_{0 m}>0.10\right)$, accretion at the toe of the structure is noticeable from the graph. These characteristics were also reported by $[1,12]$ for a plain vertical wall with a sandy foreshore slope.

For the tested spilling and plunging conditions, accretion at the slope mainly occurred for long waves with relatively low wave steepness, whereas scouring was mostly observed for short waves with relatively high wave steepness. In Figure 5, if we consider the data points that correspond to an average wave steepness of 0.02 under spilling and plunging conditions, the accretion at the structure is observed, while the experiments with relatively high wave steepness of 0.06 give scouring at the structure for a certain relative toe water depth. This can be also related with reality, where accretion at the structure is mostly observed for long waves through the onshore sediment transport of beach materials and toe scouring phenomenon under storm sea conditions due to the offshore sediment transport.

\subsection{Variation of Toe Scour Depth with Iribarren Number}

The Iribarren number or breaker parameter is generally expressed as a relationship between the structure slope and wave steepness (Equation (3)) enables distinguishing the non-breaking and breaking waves.

$$
I_{r}=\frac{\tan \propto}{\sqrt{\frac{H_{1 / 3}}{L_{0 m}}}}
$$

To observe the influence of Iribarren number $\left(I_{\mathrm{r}}\right)$ on toe scouring, the measured relative scour depths are plotted $\left(S_{t} / H_{1 / 3}\right)$ against the Iribarren number in Figure 6. One of the clear conclusions from the graph is that there is considerable variation in scour depths for similar values of the Iribarren number. This may be a result of the variation of toe water depths that has not been fully considered in Figure 6. 


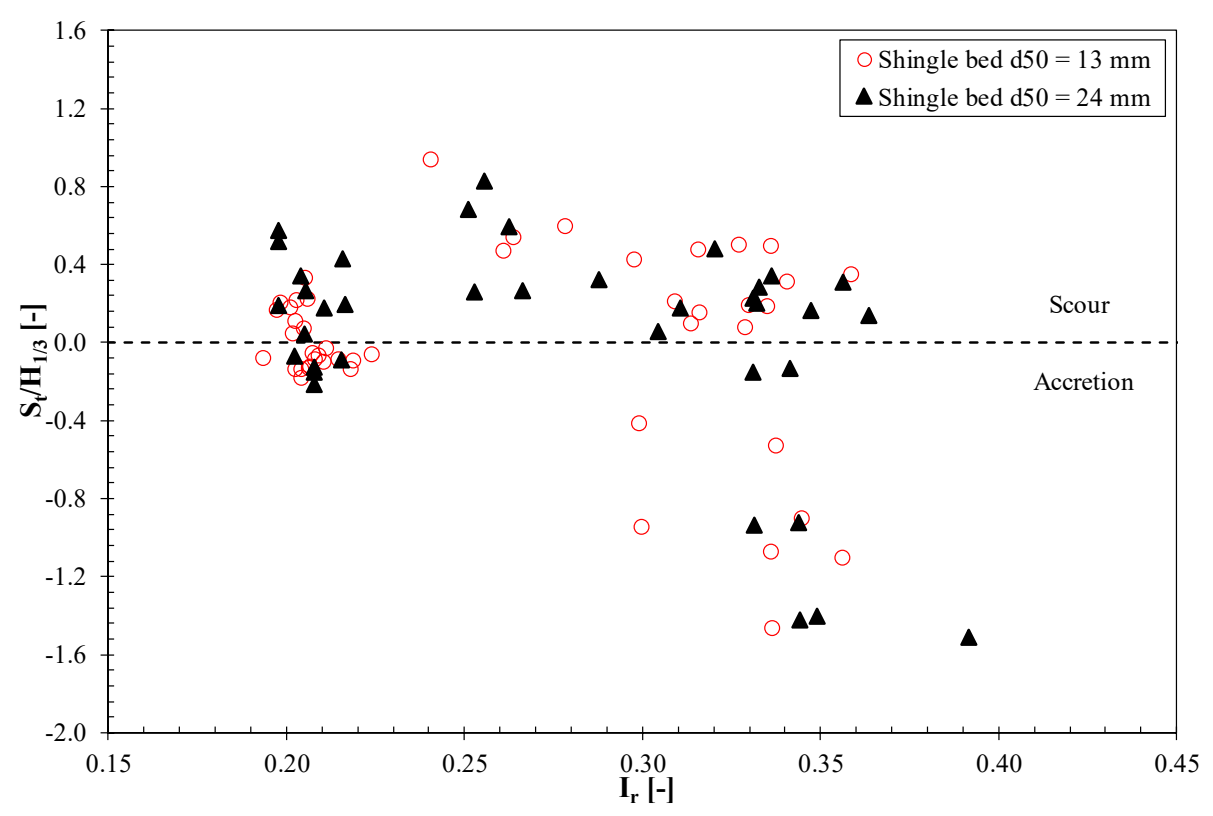

Figure 6. Variation of non-dimensional toe scour depth with Iribarren number.

\subsection{Variation of Toe Scour Depth with Relative Toe Water Depth and Iribarren Number}

The measured values of non-dimensional scour depths are plotted against dimensionless toe water depth with the data categorized into two ranges of Iribarren number to investigate the combined influence of relative water depth and Iribarren number on the scour depths, as following:

- $0.20<I_{\mathrm{r}}<0.30$ and

- $\quad I_{\mathrm{r}}>0.30$

The graph demonstrates that, for any known value of relative toe water depth $\left(h_{t} / L_{0 m}\right)$, the greatest scour depths occur for the larger Iribarren numbers, see Figure 7. Similar trends of scour depths were observed by [12] for a sloping seawall on a sandy beach foreshore.

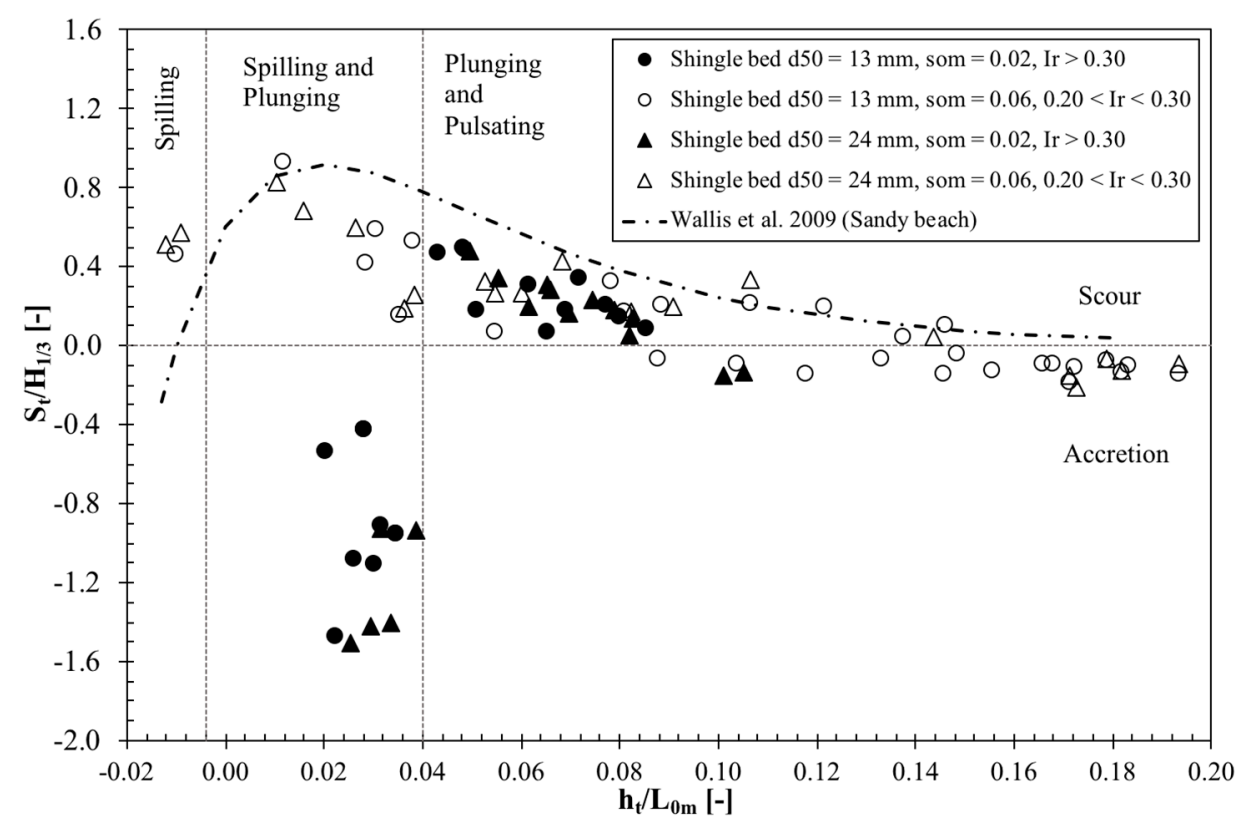

Figure 7. Variation of non-dimensional toe scour depth with Iribarren number. 


\subsection{Variation of Toe Scour Depth with Wall Slope}

To investigate the influence of wall slope on the scour depth at coastal structures, the resulting foreshore profiles of this study at 1:2 smooth sloping walls have been compared with the dataset of the plain vertical walls, as reported by [20], see Figure 8. It is important to note that, for both sloping and vertical structures, the experiments were performed with the same permeable shingle materials and inshore wave conditions, but with different structural configurations. As observed in Figure 8, the measured scour depths at sloping walls within this study do not remarkably differ from those that were reported at vertical walls by [20]. Similar characteristics of scour depths with respect to wall slope were also observed by [12] on sandy slope based on a laboratory study at 1 in 2 sloping wall and a plain vertical wall with sandy foreshore.

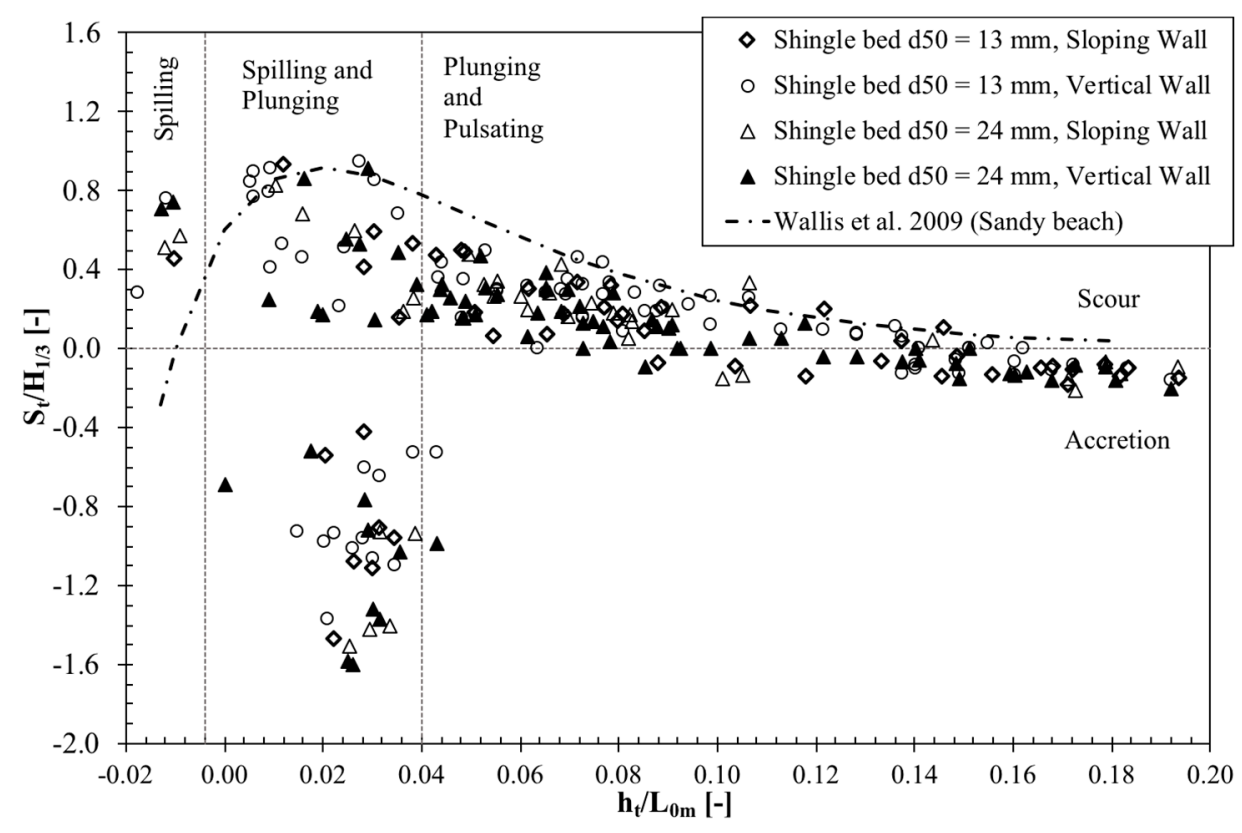

Figure 8. Variation of non-dimensional toe scour depth with wall slope.

\section{Conclusions}

This laboratory research investigated the mechanics of scour at a smooth impermeable 1 in 2 sloping wall with a uniform 1:20 permeable shingle foreshore slope. A set of small scale physical tests were carried out to measure the scour depths and the bed level changes for two different gravel foreshores. The relationship of scour depth with toe water depth, Iribarren number, and wall slope were investigated from the test results of this work and through a comparison with the available dataset in the literature. The following conclusions can be drawn based on the described study:

- The results of this study showed that the relative toe scour depth at a sloping structure on a shingle beach, is influenced by the relative toe water depth and Iribarren number.

- Within the experimental limitations, the maximum toe scour depths were observed for the experiments under the spilling and plunging wave attack $\left(0.005 \leq h_{t} / L_{0 \mathrm{~m}} \leq 0.04\right)$.

- It was found that the scour depths at the sloping walls within this study do not remarkably differ from those reported at vertical walls with similar permeable foreshore slopes, which indicates that the scour depths are independent of the slope of the structure.

It is important to note the test conditions, such as water depths, wave conditions, etc. that were followed within this study were developed by adapting the available guidelines for two-dimensional small-scale investigations, as reported in $[22,23]$ to make it comparable with typical physical model 
study. It is expected that the results of these two-dimensional hydraulic tests can be related to the prototype conditions; however, the further large-scale investigations would always be recommended.

Author Contributions: Conceptualization, M.S. and J.P.; Laboratory set-up, M.S.; Formal analysis, M.S.; Supervision-J.P.; Writing—original draft preparation, M.S.; Writing—review and editing, M.S and J.P.

Funding: This research received no external funding.

Acknowledgments: M. Salauddin would like to thank the University of Warwick Graduate School for sponsoring his PhD study through the Chancellor's International Scholarship scheme. The financial support of the Natural Environmental Research Council (Grant Ref.: NE/RE003645/1) through providing the advanced sophisticated wave analysis tools, is gratefully acknowledged. The laboratory work was financially supported through the Leverhulme Trust Senior Research Fellowships scheme (2016/2017) of the Royal Academy of Engineering The authors would also like to acknowledge the technical support of Mr. Ian Baylis of Warwick Water Laboratory in the preparation of laboratory set-up. We would also like to thank the three anonymous reviewers for their insight full comments and suggestions on the earlier draft of the manuscript.

Conflicts of Interest: This research is a part of a PhD study. The authors declare no conflict of interest. The funders had no role in the design of the study; in the collection, analyses, or interpretation of data; in the writing of the manuscript, or in the decision to publish the results.

\section{References}

1. Müller, G.; Allsop, W.; Bruce, T.; Kortenhaus, A.; Pearce, A.; Sutherland, J. The occurrence and effects of wave impacts. Proc. ICE Marit. Eng. 2008, 160, 167-173. [CrossRef]

2. Pearson, J.M. Overtopping and Toe Scour at Vertical Seawalls. In Proceedings of the 9th International Conference on Coasts, Marine structures and Breakwaters: Adapting to Change, Scotland, UK, 16-18 September 2009; Institution of Civil Engineers, Thomas Telford Ltd.: Edinburgh, UK, 2010; pp. 598-608.

3. Powell, K.A. Toe Scour at Sea Walls Subject to Wave Action: A Literature Review; Report SR 119; HR Wallingford: Wallingford, UK, 1987.

4. Fowler, J.E. Scour Problems and Methods for Prediction of Maximum Scour at Vertical Seawalls; Technical Report CERC-92-16; US Army Corps of Engineers Waterways Experiment Station, Coastal Engineering Research Center: Vicksburg, MS, USA, 1992.

5. Sutherland, J.; Brampton, A.H.; Motyka, G.; Blanco, B.; Whitehouse, R.J.W. Beach Lowering in Front of Coastal Structures—Research Scoping Study; Report FD1916/TR; Defra-Flood Management Division: London, UK, 2003. Available online: http://sciencesearch.defra.gov.uk/ (accessed on 14 February 2017).

6. Cohen-Shacham, E.; Walters, G.; Janzen, C.; Maginnis, S. Nature-Based Solutions to Address Global Societal Challenges; IUCN: Gland, Switzerland, 2016.

7. Church, J.A.; Clark, P.U.; Cazenave, A.; Gregory, J.M.; Jevrejeva, S.; Levermann, A.; Merrifield, M.A.; Milne, G.A.; Nerem, R.S.; Nunn, P.D. Sea level change. In Climate Change 2013: The Physical Science Basis Contribution of Working Group I to the Fifth Assessment Report of the Intergovernmental Panel on Climate Change; Stocker, T.F., Qin, D., Plattner, G.-K., Tignor, M., Allen, S.K., Boschung, J., Nauels, A., Xia, Y., Bex, V., Midgley, P.M., Eds.; Cambridge University Press: Cambridge, UK; New York, NY, USA, 2013.

8. Wallis, M.; Whitehouse, R.; Lyness, N. Development of guidance for the management of the toe of coastal defence structures. In Proceedings of the Presented in the 44th Defra Flood and Coastal Management Conference, Telford, UK, 30 June -2 July 2009.

9. Xie, S.L. Scouring Patterns in Front of Vertical Breakwaters and Their Influences on the stability of the Foundation of the Breakwaters. Master's Thesis, Department of Civil Engineering, Delft University of Technology, Delft, The Netherlands, 1981.

10. Kraus, N.C.; Smith, J.M. SUPERTANK Laboratory Data Collection Project. Volume 1: Main Text; Technical Report CERC-94-3; US Army Corps of Engineers Waterways Experiment Station, Coastal Engineering Research Center: Vicksburg, MS, USA, 1994; pp. 2191-2204.

11. Pearce, A.; Sutherland, J.; Müller, G.; Rycroft, D.; Whitehouse, R. Scour at a seawall-field measurements and physical modelling. In Proceedings of the 30th International Conference on Coastal Engineering, ASCE, San Diego, CA, USA, 2-8 September 2006.

12. Sutherland, J.; Obhrai, C.; Whitehouse, R.; Pearce, A. Laboratory tests of scour at a seawall. In Proceedings of the 3rd International Conference on Scour and Erosion, CURNET, Technical University of Denmark, Gouda, The Netherlands, 3-5 July 2007. 
13. Jayaratne, R.; Premaratne, B.; Adewale, A.; Mikami, T.; Matsuba, S.; Shibayama, T.; Esteban, M.; Nistor, I. Failure Mechanisms and Local Scour at Coastal Structures Induced by Tsunami. Coast. Eng. J. 2016, 58, 1640017. [CrossRef]

14. Pourzangbar, A.; Saber, A.; Yeganeh-Bakhtiary, A.; Ahari, L.R. Predicting scour depth at seawalls using GP and ANNs. J. Hydroinform. 2017, 19, 349-363. [CrossRef]

15. Tahersima, M.; Yeganeh-Bakhtiary, A.; Hajivalie, F. Scour pattern in front of vertical breakwater with wave overtopping. J. Coast. Res. 2011, 64, 598.

16. Tofany, N.; Ahmad, M.; Kartono, A.; Mamat, M.; Mohd-Lokman, H. Numerical modeling of the hydrodynamics of standing wave and scouring in front of impermeable breakwaters with different steepnesses. Ocean Eng. 2014, 88, 255-270. [CrossRef]

17. Sutherland, J.; Brampton, A.H.; Obrai, C.; Dunn, S.; Whitehouse, R.J.W. Understanding the Lowering of Beaches in Front of Coastal Defence Structures, Stage 2-Research Scoping Study; Report FD1927/TR; Defra-Flood Management Division: London, UK, 2008. Available online: http://sciencesearch.defra.gov.uk/ (accessed on 20 February 2017).

18. Powell, K.A.; Lowe, J.P. The scouring of sediments at the toe of seawalls. In Proceedings of the Hornafjordor International Coastal Symposium, Hofn, Iceland, 20-24 June 1994; pp. 749-755.

19. Jayaratne, R.; Mendoza, E.; Silva, R.; Gutiérrez, F. Laboratory Modelling of Scour on Seawalls. In Proceedings of the Presented in the International Conference on Coastal Structures, Boston, MA, USA, 9-11 September 2015.

20. Salauddin, M.; Pearson, J.M. Wave overtopping and toe scouring at a plain vertical seawall with shingle foreshore: A Physical model study. Ocean Eng. 2019, 171, 286-299. [CrossRef]

21. Powell, K.A. Predicting Short Term Profile Response for Shingle Beaches; Report SR 219; HR Wallingford: Wallingford, UK, 1990.

22. Eurotop. EurOtop II-Manual on Wave Overtopping of Sea Defences and Related Structures: An Overtopping Manual Largely Based on European Research, But for Worldwide Application. 2016. in press. Available online: www.overtopping-manual.com (accessed on 21 January 2017).

23. Wolters, G.; Van Gent, M.; Allsop, N.W.H.; Hamm, L.; Mühlestein, D. HYDRALAB III: Guidelines for physical model testing of rubble mound breakwaters. In Proceedings of the 9th International Conference on Coasts, Marine Structures and Breakwaters: Adapting to Change, Edinburgh, UK, 16-18 September 2009; pp. 659-670.

24. Mansard, E.P.D.; Funke, E.R. The measurement of incident and reflected spectra using a least squares method. Coast. Eng. 1980, 1, 154-172.

25. Klopman, G.; Van der Meer, J.W. Random wave measurements in front of reflective structures. J. Waterw. Port Coast Ocean Eng. 1990, 125, 39-45. [CrossRef]

26. Sumer, B.M.; Fredsøe, J. Experimental study of 2D scour and its protection at a rubble-mound breakwater. Coast. Eng. 2000, 40, 59-87. [CrossRef]

27. Sherman, D.J. Gravel beaches. Natl. Geogr. Res. Explor. 1991, 7, 442-452.

(C) 2019 by the authors. Licensee MDPI, Basel, Switzerland. This article is an open access article distributed under the terms and conditions of the Creative Commons Attribution (CC BY) license (http://creativecommons.org/licenses/by/4.0/). 